\title{
PENGARUH IKLAN OBAT FLU DI TELEVISI TERHADAP PERILAKU SWAMEDIKASI
}

\author{
Nurul Mardiati ${ }^{1}$, Robiatul Islamiah ${ }^{2}$, Rahmayanti Fitriah $^{3}$ \\ ${ }^{1,2}$ Program Studi DIII Farmasi, Sekolah Tinggi Ilmu Kesehatan Borneo Lestari \\ ${ }^{3}$ Program Studi S1 Farmasi, Sekolah Tinggi Ilmu Kesehatan Borneo Lestari \\ Email korespondensi: nurulmardiati2007@gmail.com
}

\begin{abstract}
ABSTRAK
Tingginya prevalensi flu dan tersedianya obat dipasaran dengan mudah serta harga yang relatif terjangkau menjadikan salah satu pendorong tindakan swamedikasi flu oleh masyarakat. Selain itu, kemajuan teknologi yang semakin canggih membuat masyarakat mudah dalam mendapatkan informasi, salah satunya iklan obat di televisi yang dapat mempengaruhi perilaku konsumen dalam pemilihan obat yang digunakan dalam tindakan swamedikasi. Penelitian ini dilakukan dengan tujuan untuk mengetahui pengaruh iklan obat flu di televisi terhadap perilaku swamedikasi pada masyarakat Kecamatan Karang Intan. Metode penelitian ini merupakan penelitian yang bersifat deskriptif observasional dengan rancangan cross sectional. Teknik pengambilan sampel dilakukan menggunakan metode non random sampling yaitu accidental sampling, dan didapatkan jumlah responden sebanyak 100 orang. Data yang dikumpulkan berasal dari data kuesioner, yang diisi oleh responden didampingi oleh peneliti. Analisis data secara deskriptif dilakukan dengan uji chi square. Hasil penelitian menunjukkan bahwa pengaruh iklan obat flu di televisi terhadap perilaku swamedikasi pada masyarakat Kecamatan Karang Intan memiliki nilai signifikan $\mathrm{p}$ yaitu 0,000. Kesimpulan yang didapat yaitu iklan obat flu di televisi mempunyai pengaruh terhadap perilaku swamedikasi pada masyarakat Kecamatan Karang Intan.
\end{abstract}

Kata kunci : Iklan Obat, Swamedikasi Flu, Kecamatan Karang Intan 


\title{
THE EFFECT OF FLU DRUG ADVERTISING ON TELEVISION ON SWAMEDICATION BEHAVIOR
}

\begin{abstract}
The high prevalence of flu and the easy availability of drugs in the market and at relatively affordable prices are one of the driving forces for self-medicating by the community. In addition, increasingly sophisticated technological advances make it easy for people to get information, one of which is drug advertisements on television that can influence consumer behavior in the selection of drugs used in self-medication. This research was conducted with the aim of knowing the effect of cold medicine advertisements on television on self-medication behavior in the community of Karang Intan District. This research method is a descriptive observational study with a cross sectional design. The sampling technique was carried out using non-random sampling method, namely accidental sampling, and the number of respondents was 100 people. The data collected comes from questionnaire data, which is filled in by respondents accompanied by researchers. Descriptive data analysis was performed by using the chi square test. The results showed that the effect of cold medicine advertisements on television on self-medicated behavior in the community of Karang Intan District has a significant $p$ value of 0.000. The conclusion is that the advertisement of cold medicine on television has an influence on self-medication behavior in the community of Karang Intan District.
\end{abstract}

Keywords : Drug Advertisement, Flu Medicine, Karang Intan District

\section{PENDAHULUAN}

Salah satu hal yang sangat penting dalam kehidupan masyarakat adalah kesehatan, ketika seseorang merasa sakit maka seseorang tersebut akan berusaha untuk mendapatkan kesehatannya kembali. Pilihan yang dilakukan untuk mendapatkan kesembuhan dari suatu penyakit, yaitu dengan berobat ke dokter atau mengobati diri sendiri. Menurut Departemen Kesehatan Republik Indonesia (2008), upaya yang paling banyak dilakukan masyarakat untuk mengatasi gejala penyakit sebelum mencari pertolongan dari tenaga kesehatan adalah pengobatan diri sendiri atau yang biasa disebut dengan swamedikasi. Data faktual berdasarkan Survei Sosial Ekonomi Nasional-Badan Pusat Statistik (SUSENAS-BPS, 2009), menunjukkan bahwa $66,8 \%$ orang sakit di Indonesia melakukan swamedikasi sebagai usaha pertama dalam menanggulangi penyakitnya. Persentase tersebut cenderung lebih tinggi dibandingkan $33,2 \%$ penduduk yang langsung berobat jalan ke dokter. 
Swamedikasi atau pengobatan sendiri adalah tindakan yang dilakukan untuk mengatasi masalah kesehatan dengan menggunakan obat-obatan baik itu obat modern, herbal maupun tradisional yang dapat dikonsumsi tanpa pengawasandokter. Obat-obatan yang digunakan untuk pengobatan sendiri atau swamedikasi biasa disebut dengan OTC (over the counter). Data faktual menunjukkan bahwa $66 \%$ orang sakit di Indonesia melakukan swamedikasi sebagai usaha pertama dalam menanggulangi penyakitnya. Persentase tersebut cenderung lebih tinggi dibandingkan $34 \%$ penduduk yang langsung berobat jalan ke dokter (BPS, 2009). Berdasarkan hasil Riset Kesehatan Dasar (RISKESDAS) tahun 2013 di Indonesia terdapat sejumlah 103.860 atau $35,2 \%$ dari 294.959 rumah tangga di Indonesia menyimpan obat untuk swamedikasi, dengan proporsi tertinggi di DKI Jakarta $(56,4 \%)$ dan terendah di Nusa Tenggara Timur (17,2\%). Meski begitu, tingginya angka ini harus tetap diwaspadai karena pasalnya pada pelaksanaan swamedikasi diprediksi akan banyak terjadi kesalahan penggunaan obat (medication error) yang disebabkan karena keterbatasan pengetahuan masyarakat akan obat dan penggunaanya (Depkes, 2006).

Berdasarkan data pengawasan iklan obat yang telah dilakukan oleh Badan Pengawas Obat dan Makanan tahun 2012, iklan obat yang beredar pada media seperti

televisi, media cetak dan radio yang tidak memenuhi ketentuan peraturan periklanan obat bebas, obat tradisional, kosmetika, makanan minuman, perbekalan kesehatan rumah tangga, dan alat kesehatan sebanyak 565 $(23,88 \%)$ iklan dari total 2.366 iklan dan ditindaklanjuti dengan peringatan sebanyak $551(97,52 \%)$ iklan serta yang ditindak lanjuti dengan peringatan keras sebanyak 14 (2,48\%) iklan. Hal ini terjadi karena iklan yang ditayangkan banyak yang tidak melalui tahap prereview dengan mengiklankan langsung tanpa melalui tim penilai iklan yaitu sensor Badan POM (Turisno, 2012). Banyaknya iklan obat di televisi yang tidak sesuai dengan ketentuan periklanan, dikhawatirkan dapat menyebabkan interpretasi yang salah pada masyarakat tentang penggunaan obat dalam tindakan pengobatan sendiri (swamedikasi) (Dianawati et al., 2008).

Sejauh ini penelitian serupa sudah pernah dilakukan antara lain oleh Tri Lusi Kusumati (2017) dan Hidajah Rachmawati (2011). Akan tetapi penelitian oleh Tri Lusi Kusumawati, subjek penelitiannya terbatas pada kalangan mahasiswa program studi non kesehatan di Universitas Muhammadiyah Yogyakarta. Sedangkan penelitian oleh Hidajah Rachmawati sendiri yang dilakukan di Malang, teknik pengambilan sampelnya hanya menggunakan purposive sampling tanpa mengombinasikannya dengan teknik proportional random sampling sehingga kurang representatif menggambarkan subjek penelitian. Tempat penelitian ini di Kecamatan Karan Intan Kabupaten Banjar. Kecamatan Karang Intan merupkan 
kerena lokasi tersebut padat dengan penduduk sehingga arus informasi cukup cepat dengan tingkat pendidikan dan pengetahuan cukup tinggi, dan sebelumnya belum pernah dilakukan penelitian mengenai pengaruh iklan obat flu terhadap perilaku swamedikasi. Tujuan penelitian ini yaitu mengetahui pengaruh iklan obat flu di televisi terhadap perilaku swamedikasi pada masyarakat Kecamatan Karang Intan

\section{METODE PENELITIAN}

\section{Rancangan Penelitian}

Penelitian ini menggunakan jenis penelitian survei, jenis penelitian ini termasuk dalam penelitian deskriftif analisis dengan rancangan cross sectional.

\section{Tempat dan Waktu Penelitian}

Penelitian dilakukan di

Kecamatan Karang Intan Kabupaten Banjarbaru bulan April - Mei 2018.

\section{Populasi dan sampel}

\section{Populasi}

Populasi pada penelitian ini adalah warga yang tinggal di Kecamatan Karang Intan, dengan jumlah penduduk sebanyak 34.169 jiwa.

2. Sampel Penelitian

Sampel penelitian ini adalah penduduk Kecamatan Karang Intan yang pernah melakukan pengobatan sendiri menggunakan obat flu. Teknik pengambilan sampel ini menggunakan salah satu cakupan metode non random sampling yaitu accidental sampling. Besar sampel pada penelitian ini menggunakan rumus Slovin:

$$
\begin{aligned}
& \mathrm{n}=\frac{N}{1+N(d) 2} \\
& \mathrm{n}=\frac{34169}{1+34169(0,01)} \\
& \mathrm{n}=\frac{34169}{342,69} \\
& \mathrm{n}=99,7
\end{aligned}
$$

Keterangan:

$\mathrm{N}=$ Besar populasi

$\mathrm{n}=$ Besar sampel

$\mathrm{d}=$ Tingkat kepercayaan / ketepatan yang diinginkan

Dalam penelitian ini peneliti mengambil responden sebanyak 100 yang diharapkan dapat menjaga validitas penelitian ini.

\section{Kriteria Inklusi dan Ekslusi}

1. Kriteria Inklusi

Kriteria inklusi penelitian ini meliputi:

a. Tercatat sebagai warga Kecamatan Karang Intan dapat diketahui melalui Kartu Tanda Penduduk (KTP)

b. Bersedia menjadi responden

c. Pernah menggunakan obat flu (obat bebas, bebas terbatas, obat tradisional) secara untuk swamedikasi

d. Pernah menyaksikan iklan obat flu di televisi

e. Berusia $\square 18$ tahun.

2. Kriteria eksklusi

Kriteria eksklusi penelitian ini meliputi:

a. Berprofesi sebagai tenaga kesehatan

https://doi.org/10.33759/jrki.v3i1.103 
b. Sakit berat yang menyulitkan penelitian dan responden untuk berkomunikasi dengan peneliti

\section{Instrumen Penelitian}

Instrumen yang digunakan dalam penelitian berupa kuesioner yang terdiri dari tiga bagian, pertama data karakteristik responden. Kedua, pengaruh terhadap iklan obat flu di televisi. Ketiga, perilaku swamedikasi dengan obat flu. Kuesioner merupakan bentuk adopsi dari penelitian oleh Adawiyah (2015). Instrumen yang digunakan dalam penelitian, sebelumnya dilakukan uji validitas dan reliabilitas.

\section{Variabel Penelitian}

Penelitian ini melibatkan dua variabel, yaitu pengaruh iklan obat flu sebagai variabel bebas dan perilaku swamedikasi dengan obat flu sebagai variabel terikat.

\section{Pengolahan Data}

Pengolahan data penelitian dilakukan dengan melalui tahapan sebagai berikut: 1. Editing, merupakan kegiatan penyuntingan data yang terkumpul dengan cara memeriksa kelengkapan data dan kesalahan pengisian kuesioner untuk memastikan data yang diperoleh tekah lengkap dapat dibaca dengan baik, relevan, dan konsisten.

2. Coding, setelah melakukan proses editing kemudian dilakukan pengkodean terhadap setiap variabel sebelum diolah dengan computer dengan tujuan untuk memudahkan menganalisis data.

3. Entry data, merupakan proses memasukkan data dari kuesioner ke dalam komputer untuk kemudian diolah dengan bantuan perangkat lunak komputer.

4. Cleaning, proses pengecekan kembali dari pemeriksaan kesalahan pada data yang sudah di-entry untuk diperbaiki dan disesuaikan dengan data yang dikumpulkan.

\section{Analisis Data}

Data yang diolah kemudian dianalisis menggunakan program SPSS (statistical

Package for the Social Scienes) versi 21. Analisis data yang dilakukan berdasarkan literatur seperti MIMS dan ISO. Statistik deskriptif menggunakan teknik persentase, metode ini digunakan untuk mendapatkan gambaran distribusi frekuensi serta distribusi jawaban responden. Data yang diolah selanjutnya dianalisis dengan uji chi square.

\section{HASIL DAN PEMBAHASAN Uji Validitas dan Reliabilitas}

Kuesioner ini diuji coba pada 30 responden. Pengujian validitas (korelasi) dilakukan dengan cara membandingkan nilai $r$ hitung dengan $r$ tabel. Apabila hasil pengujian menunjukkan $r$ hitung lebih besar dari $r$ tabel, berarti ada korelasi (H0 ditolak) atau pertanyaan memiliki validitas. Hasil uji validitas menunjukkan ada 9 pertanyaan yang valid, dan ada 3 yang tidak valid berturut-turut nilai $r$ 
hitungnya yaitu $-0,025 ; 0,325$ dan 0,326 .

Koefisien reliabilitas dalam penelitian ini diukur dengan analisis reliabilitas yang menggunakan koefisien Cronbach's Alpha. Jika nilai Cronbach's Alpha lebih besar dari 0,600, maka kuesioner dapat dinyatakan reliabel. Hipotesis yang akan di uji dalam uji reliabilitas adalah sebagai berikut:

$\mathrm{HO}=$ Kuesioner tidak bisa memberikan hasil yang konsisten sebagai alat ukur hitung < 0,6)

$\mathrm{H} 1$ = Kuesioner dapat memberikan hasil yang konsisten sebagai alat ukur ( $\mathrm{r}$ hitung $=0,6$ )

Berdasarkan hasil perhitungan uji reliabilitas didapat nilai Cronbach's Alpha Kuesioner lebih besar dari standar minimal agar Kuesioner dapat dijadikan sebagai alat

ukur. Keputusan yang diambil adalah tolak H0 dan terima H1. Kesimpulannya adalah Kuesioner yang digunakan untuk menganalisis pengaruh iklan obat flu di televisi terhadap perilaku swamedikasi pada masyarakat Kecamtan Karang Intan dapat dijadikan alat ukur yang reliabel dan memberikan hasil yang konsisten.

\section{Karakteristik Responden}

Karakteristik responden pada penelitian ini meliputi, umur, jenis kelamin, pendidikan terakhir, dan pekerjaan

Tabel I. Distribusi Frekuensi Karakteristik Responden

\section{No. Karakteristik Responden $\quad$ Frekuensi}

(Persentase)

1 Umur
a) 18-27 tahun
$31(31 \%)$
b) 28-38 tahun
$20(20 \%)$
c) 39-49 tahun
$30(30 \%)$
d) 50-60 tahun
$19(19 \%)$

2 Jenis Kelamin
a) Perempuan
$61(61 \%)$
b) Laki-laki
$39(39 \%)$

3 Pendidikan Terakhir
a) $\mathrm{SD}$
$27(27 \%)$
b) SMP
$23(23 \%)$
c) $\mathrm{SMA} / \mathrm{SMK}$
$35(35 \%)$
d) Perguruan Tinggi
$15(15 \%)$

4 Pekerjaan

a) Ibu Rumah Tangga $\quad 41(41 \%)$ 
b) Wiraswasta

c) Pegawai Negeri Sipil

d) Mahasiswa

e) Pegawai Swasta

f) Guru Honorer
$9(9 \%)$

$11(11 \%)$

$9(9 \%)$

$20(20 \%)$

$10(10 \%)$
1. Umur Responden

$$
\text { Hasil }
$$

penelitian

menunjukkan

mayoritas

responden dengan umur 18-28

tahun 31 orang $(31 \%)$ yang merupakan usia dewasa awal.

Menurut Santrock (2009), dewasa awal adalah masa peralihan dari remaja. Hasil penelitian Dianawati et al. (2008), menunjukkan remaja yang berada pada usia yang dikategorikan usia remaja lanjut mempunyai karakter mulai mempunyai keinginan untuk membuat keputusan sendiri dan mencoba sesuatu yang baru dan menarik. Adanya televisi memberi rekomendasi bagi remaja untuk pemilihan dan penggunaan obat.

2. Jenis Kelamin Responden Jenis kelamin responden didominasi perempuan 61 orang (61\%). Menurut Anna dan Chandra (2011) pada dasarnya perempuan lebih peduli terhadap kesehatan dibanding kaum laki-laki. Menurut penelitian yang dilakukan oleh Adawiyah (2015), responden yang menonton televisi lebih besar dibandingkan dengan kaum laki-laki yaitu sebesar $69,4 \%$.
3. Pendidikan Terakhir Responden Pendidikan terakhir responden mayoritas adalah SMA (35\%). Menurut Supardi \& Raharni (2006), responden dengan tingkat pendidikan terakhir SMA atau sederajat termasuk dalam kategori pendidikan lanjutan. Kebanyakan orang-orang dengan tingkat pendidikan tersebut menggunakan obat-obat bebas untuk pengobatan penyakit ringannya (Islam, 2007).

4. Pekerjaan Responden

Hasil penelitian responden yang pernah melihat iklan obat flu di televisi dan menggunakan obat flu secara swamedikasi adalah ibu rumah tangga (41\%). Berdasarkan penelitian yang dilakukan oleh Fauzia (2014) di Purwakarta, ibu rumah tangga banyak melakukan pengobatan sendiri dengan alasan, tidak perlu membuang-buang uang untuk membayar transportasi ke puskesmas, obat yang mereka perlukan jika sakit dengan mudah ditemukan di warung dengan harga terjangkau dengan sumber informasi melalui iklan di televisi. 


\section{Pengaruh Iklan Obat Flu di Televisi}

Data pengaruh iklan obat di televisi dibagi dalam dua kategori yaitu tidak terpengaruh iklan obat di televisi dan terpengaruh iklan obat di televisi.

Tabel II. Distribusi Frekuensi Pengaruh Iklan Obat Flu di Televisi

\begin{tabular}{cc}
\hline $\begin{array}{c}\text { Kategori Pengaruh Iklan } \\
\text { Obat Flu di Televisi }\end{array}$ & $\begin{array}{c}\text { Frekuensi } \\
\text { (Persentase) }\end{array}$ \\
\hline Terpengaruh & $73(73 \%)$ \\
Tidak Terpengaruh & $27(27 \%)$ \\
\hline
\end{tabular}

\section{Kategori:}

1. Terpengaruh iklan obat di televisi, bila responden memperoleh skor $=24$

2. Tidak terpengaruh iklan obat di televisi, bila responden memperoleh skor $<24$.

Mayoritas responden yaitu 73 orang $(73 \%)$ terpengaruh iklan obat flu di televisi. Hasil penelitian sesuai dengan penelitian oleh Rachmawati (2011) yang menyatakan bahwasanya iklan obat flu di televisi berpengaruh positif terhadap pemilihan obat flu secara swamedikasi oleh masyarakat di Malang. Hasil penelitian Jamilah (2003) menunjukkan bahwa persepsi konsumen terhadap iklan di televisi adalah mudah dipahami pesannya, menarik, dapat dipercaya, dan sesuai dengan kondisi/kebutuhan, sehingga dari persepsi tersebut dapat mempengaruhi pengambilan keputusan pembelian (intensitas pembelian). Menurut Sumarwan et al. (2012) keberadaan iklan penting dalam pembentukan pengaruh konsumen.

Perilaku Swamedikasi dengan Obat Flu

$$
\text { Data perilaku swamedikasi }
$$
dengan obat flu dibagi dalam dua kategori yaitu tepat dan tidak tepat

Tabel II. Distribusi Frekuensi Perilaku Swamedikasi dengan Obat Flu

\begin{tabular}{cc}
\hline $\begin{array}{c}\text { Kategori Perilaku } \\
\text { Swamedikasi dengan } \\
\text { Obat Flu }\end{array}$ & $\begin{array}{c}\text { Frekuensi } \\
\text { (Persentase) }\end{array}$ \\
\hline Tepat & $73(73 \%)$ \\
Tidak Tepat & $27(27 \%)$ \\
\hline
\end{tabular}

Kategori:

1. Perilaku swamedikasi tidak tepat, bila responden memperoleh skor $<7$

2. Perilaku swamedikasi tepat, bila responden memperoleh skor $=7$

Responden yang melakukan flu sebagian besar 74 orang( $74 \%)$. swamedikasi dengan menggunakan obat Menurut Kristina et al. (2008), kriteria 
ketepatan penggunaan obat terdiri dari ketepatan indikasi, kesesuaian dosis, ada tidaknya kontraindikasi, ada tidaknya efek samping dan interaksi dengan obat dan makanan, serta ada tidaknya polifarmasi. Perbedaan informasi yang seharusnya dimuat dalam iklan dengan kriteria rasionalitas dapat menyebabkan ketidak rasionalan perilaku swamedikasi seseorang.

\section{Pengaruh Iklan Obat di Televisi terhadap Perilaku Swamedikasi}

Berdasarkan uji chi square yang dilakukan diperoleh nilai Sig $(\mathrm{p}=$ value $)$ 0,000. Sedangkan nilai taraf Signifikansi $<0,05$; maka nilai $\mathrm{p}=$ value $, 000<0,05$. Artinya ada pengaruh signifikan iklan obat terhadap perilaku swamidekasi. Menurut Dianawati et al.(2008), persepsi terhadap iklan obat di televisi memberikan pengaruh yang signifikan terhadap perilaku swamedikas. Jika persepsi terhadap iklan obat semakin kuat, maka perilaku swamedikasi yang dilakukan akan menunjukkan indikasi penyimpangan yang makin besar pula.

\section{SIMPULAN}

Kesimpulan dari penelitian ini adalah ada pengaruh iklan obat flu di televisi terhadap perilaku swamedikasi pada masyarakat Kecamatan Karang Intan.

\section{UCAPAN TERIMAKASIH}

Pada kesempatan ini, peneliti ingin mengucapkan terima kasih kepada kepada pihak yang telah membantu terwujudnya penelitian ini :
1. Camat Kecamatan Karang Intan yang telah memberikan izin penelitian

2. Masyarakat Kecamatan Karang Intan yang telah bersedia menjadi responden

\section{DAFTAR PUSTAKA}

Adawiyah, S. (2015). Hubungan Persepsi Terhadap Iklan Obat Laktasif Di Televisi

Dengan Perilaku Swamedikasi Masyarakat Di Kelurahan Sungai Besar Kecamatan Banjarbaru Selatan (Skripsi).

Departemen Kesehatan Republik Indonesia. (2008). Materi Pelatihan Peningkatan Pengetahuan Dan Keterampuilan Memilih Obat Bagi Tenaga Kesehatan. Jakarta: Departemen Kesehatan Republik Indonesia.

Departemen Kesehatan Republik Indonesia. (2006). Besar Sampel Dan Cara Pengambilan Sampel Dalam Penelitian Kedokteran dan Kesehatan . Jakarta: Salemba Medika.

Dianawati, O., Fasich, \& Athijah, U. (2008). Hubungan Persepsi Terhadap Iklan di televisi Dengan Perilaku Swamedikasi Pelajar SMU Negeri Di Surabaya. Majalah Farmasi Airlangga, 6 (1), 10-16. Diakses dari 
http://journal.unair.ac.id/downloa d-fullpapers-MFA_6_1_03.pdf

Islam, M.S. (2007). Self-medication among hohher educated population in Bangladesh;

an email-based exploratory study. The Internet Journal of Health, 5(2); 1-5. Diakses dari https://print.ispub.com/api/0/ispub -article/6868

Fauziah, R. (2014). Faktor Yang mempengaruhi Perilaku Pengobatan Sendiri Pada Kelompok Ibu Rumah Tangga Di Kabupaten Purwakarta. (Skripsi).

Kusumawati, T.L. (2017). Evaluasi Pengaruh Iklan Obat Di Televisi Terhadap Swamedikasi Flu (Common Cold)Pada Mahasiswa Program Studi Non Kesehatan Di Universitas Muhammadiyah Yogyakarta (UMY). (Skripsi).
Rahmawati, H. (2011). Pengaruh Iklan Obat Flu Ditelevisi Terhadap Pemilihan Obat

Secara Swamedikasi Pada syarat Masyarakat Di Malang. Farmasains: Jurnal Farmasi dan Ilmu Kesehatan,1(2);1-11.doi: https://doi.org/10.22219/far.v1i2.1 169

Supardi, S. \& Raharni. (2006). Penggunaan obat yang sesuai dengan aturan dalam pengobatan sendiri keluhan demam, sakit kepala, batuk flu analisis lanjut usia data Surfey Kesehatan Rumah Tangga (SKRT) 2001. Jurnal Kedokteran Yasri, 14 (1), 6069.

Turisno, B.E. (2012). Perlindungan Konsumen Dalam Iklan Obat. Masalah-Masalah Hukum, 41(1):20-28. doi: 10.14710/mmh.41.1.2012.20-28. 